\title{
The role of microRNAs in angiogenesis
}

\section{Rola mikroRNA w procesie angiogenezy}

\author{
Joanna Bujak*凶, Patrycja Kopytko*凶, Małgorzata Lubecka, Katarzyna Sokołowska, Maciej Tarnowski
}

Pomorski Uniwersytet Medyczny w Szczecinie, Katedra i Zakład Fizjologii, al. Powstańców Wlkp. 72, 70-111 Szczecin

Pomeranian Medical University in Szczecin, Chair and Department of Physiology

$\triangle$ joanna.bujak@pum.edu.pl

$\triangle$ patrycja.kopytko@pum.edu.pl

\begin{abstract}
Angiogenesis is the process that leads to the formation of new blood vessels. Under physiological conditions it occurs, inter alia, during corpus luteum formation and in some stages of the menstrual cycle. However, angiogenesis plays an essential role in many pathological conditions, particularly cancer. New blood vessel formation provides cancer cells with oxygen and essential nutrients, which stimulates tumor growth and facilitates its metastasis. Increasing evidence indicates that angiogenesis is regulated by microRNAs (miRNAs), which are small non-coding RNA molecules of 19-25 nucleotides. The main function of
\end{abstract}

miRNAs is post-transcriptional regulation of gene expression, which controls many key biological processes, including cell proliferation, differentiation and migration. Endothelial miRNAs, known as angiomiRs, are presumably involved in tumor development and angiogenesis through regulation of pro- and antiangiogenic factors. To date, the miRNAs that stimulate angiogenesis are: miR-9, miR-27a, miR-30d, miRo-130b, miR-139, miR-146a, miR-150, miR-155, miR-200c, miR-296 and miR-558. Conversely, miRNAs that inhibit angiogenesis are: miR-145, miR-519c, miR-22, miR-20a, miR-92, miR-7b, miR-221, miR-222, miR-328 and miR-101. Keywords: miRNA; angiogenesis; cancer; RNA; interference.

\section{ABSTRAKT}

Angiogeneza jest procesem prowadzącym do formowania się nowych naczyń krwionośnych. W warunkach fizjologicznych zachodzi m.in. podczas formowania się ciałka żółtego oraz w niektórych etapach cyklu menstruacyjnego. Wzmożona angiogeneza towarzyszy również wielu stanom patologicznym, w szczególności chorobom nowotworowym. Powstawanie nowotworowych naczyń krwionośnych umożliwia dostarczenie komórkom rakowym tlenu oraz niezbędnych składników odżywczych, co stymuluje wzrost guza i ułatwia jego przerzutowanie. Coraz więcej dowodów wskazuje na to, iż proces angiogenezy może być regulowany przez mikroRNA (miRNA), czyli krótkie niekodujące odcinki RNA o długości ok. 19-25 nukleotydów. Główną funkcją miRNA jest potranskrypcyjna regulacja ekspresji genów,
\end{abstract}

przez co kontrolują one wiele kluczowych procesów biologicznych, m.in.: namnażanie, różnicowanie oraz migrację komórek. Cząsteczki miRNA obecne w śródbłonku nazy wane są angiomiRami i przypuszczalnie biorą udział w procesie angiogenezy nowotworowej oraz progresji guzów poprzez regulację czynników proangiogennych lub antyangiogennych. Obecnie do grupy proangiogennych miRNA zalicza się: miR-9, miR-27a, miR-30d, miRo-13ob, miR-139, miR-146a, miR-150, miR-155, miR-200c, miR296 oraz miR-558, natomiast przedstawicielami grupy miRNA o działaniu antyangiogennym są: miR-145, miR-519c, miR-22, miR-20a, miR-92, miR-7b, miR-221, miR-222, miR-328 oraz miR-101. Słowa kluczowe: miRNA; angiogeneza; nowotwór; RNA; interferencja RNA.

\section{ANGIOGENESIS IN PHYSIOLOGICAL AND PATHOLOGICAL CONDITIONS}

Angiogenesis refers to a sequence of events that leads to the formation of new blood vessels from existing vessels. The formation of new blood vessel networks is a physiological process necessary for organismal development and function. This process occurs during non-fertile life and involves the so-called budding of endothelial cells (sprouting angiogenesis). Physiological angiogenesis occurs, for example, during the formation of the corpus luteum or in the endometrium during certain menstrual cycle stages. Proper implantation of the embryo in the endometrium and subsequent placenta formation would not be possible without this vascularisation mechanism [1].

Angiogenesis is also essential for many pathological processes. Like any mechanism that occurs in the body, the process of creating new blood vessels is strictly controlled. A number of pro- and antiangiogenic factors are responsible for proper vascularisation. When the balance between the pro- and antiangiogenic factors is disturbed and tilted to the side of factors that stimulate vascularisation, excessive blood vessel formation occurs. The pathological occurrence and course of vascularisation is observed in chronic inflammation and the development of ischaemic diseases. However, the most significant disease in which there is increased blood vessel production is cancer [2]. The formation and development of neoplastic blood vessels consists of 3 processes: tumor angiogenesis, intussusception, and vascular mimicry. Angiogenesis represents the formation of blood vessels from existing tumor vessels. Intussusception is the mechanism of disintegration of one larger vessel into smaller vessels, and vascular mimicry is characterised by the formation of vascular-like structures that resemble functional

* These authors contributed equally to this work. 
blood vessels [2,3]. Tumors secrete their own growth factors to produce an independent blood vessel network. This mechanism is extremely important in cancer development and progression. Indeed, cancerous tumor growth potential depends on the degree of vascularisation. This blood vessel network creates an immunosuppressive environment around the tumor, a phenomenon that allows the cancer tissue to avoid immune system recognition and escape apoptosis. Additionally, tumor vaccinations allow cancer cells to spread throughout the body, thus initiating metastasis. These events are all possible thanks to the tumor's own vessels, which also transport the necessary nutrients to maintain tumor function [1]. This newly created cancer-induced blood vessel network does not resemble normal physiological vessels. Rather, the vessels exhibit altered morphology and a chaotic course. They form a convoluted system characterised by increased permeability with variable diameter and branch numbers. These abnormalities slow blood flow through the tumor vessels and promote hypoxia [4, 5]. Cancerous tissue that undergoes hypoxia is subject to a compensatory mechanism, namely increased production of proangiogenic factors, which subsequently induces the formation of new (abnormal) blood vessels, which in turn are the main cause of hypoxia. The process of creating new cancer-derived blood vessels therefore resembles a 'vicious circle' that promotes tumor progression [6].

Blood vessel formation under physiological conditions is strictly controlled by a number of pro- and antiangiogenic factors, including myriad cytokines and cell mediators. The most important factors that stimulate angiogenesis are growth factors such as vascular endothelial growth factor (VEGF), plateletderived growth factor (PDGF), fibroblast growth factor (FGF), cytokines (interleukin-1, interleukin-6 and interleukin-8), some proteases, trace elements, oncogenes and others. The secretion of certain angiogenesis-inducing factors is regulated at the post-transcriptional level; the key regulator is non-coding microRNA (miRNA) $[1,7]$.

\section{microRNA - BRIEF HISTORY, BIOGENESIS AND FUNCTIONS}

MicroRNAs were first described in 1993 during studies on Caenorhabditis elegans development when 2 lin-14 gene transcripts were detected. The shorter transcript ( 22 nucleotides) had a sequence complementary to the lin-14 messenger RNA (mRNA) and is its negative regulator. Further studies demonstrated that inhibition of lin-14 gene expression occurs via interaction of antisense RNA with the mRNA of the target gene. These observations led scientists to search a new group of molecules that could inhibit gene expression. In 2001, 3 independent research centres defined this novel group and named it miRNA $[8,9]$.

MicroRNAs belong to a large family of endogenous singlestranded RNA. Their length ranges 19-25 nucleotides. MicroRNA occur in the majority of living organisms, including humans, other animals, plants, fungi, bacteria and viruses. According to the latest research, the human body contains more than 800 different miRNAs; approx. 3\% of all genes code for these molecules [10]. Most of the known miRNAs are encoded within introns or in exon noncoding RNA regions. Some microRNA-coding loci are located far away from each other and form their own autonomous transcription units, while others are clustered in one region and exhibit similar expression patterns, a phenomenon that suggests they are transcribed as polycistronic transcripts [9].

The current miRNA biogenesis model assumes that they are transcribed by RNA polymerase II, a process that produces pri-miRNA. The original transcripts arise in the cell nucleus, are double-stranded and hundreds of nucleotides long [11]. The pri-miRNA molecule is polyadenylated at the 3 ' end, while the 5 ' end has a cap. The original transcripts form a closed structure, which is conditioned by the presence of a characteristic 'hairpin' structure. Under the influence of Drosha endonuclease activity and DGCR8 protein, it is cut to release 70 nucleotide dspre-miRNA segments. Next, the pre-miRNA is combined with exportin- 5 protein and transported to the cytoplasm using energy derived from guanosine triphosphate (GTP) hydrolysis. In the cytosol, the double-stranded premiRNA is cleaved with the Dicer enzyme to form short-term miRNA::miRNA * complexes. The resulting complex is unstable and is thus cleaved into short nucleotide chains (21-25 nucleotides), which represent mature miRNAs $[8,12,13]$.

The main miRNA function is post-transcriptional regulation of gene expression, which controls many key biological processes, including cell proliferation, differentiation and migration [13]. MicroRNAs create complicated regulatory networks; a single miRNA can regulate the expression of several genes. Further, several miRNAs may bind as a group and cooperate to control a single gene [14]. MicroRNA can regulate gene activity in 2 ways. The 1st is complete degradation of the target gene mRNA. This process occurs with a minimum of 7-8 nucleotide complementarity between the miRNA sequence and target mRNA. In this case, the mRNA undergoes hydrolytic degradation via endonuclease activity [15]. The 2 nd method, which occurs more frequently in humans and animals, is gene expression silencing, where translation is inhibited. In this process, there is incomplete complementarity between the miRNA and mRNA sequences. The mechanism involves attachment of the miRNA molecule to the 3 ' end of the mRNA, which inhibits protein synthesis $[16,17]$.

In humans, miRNA regulates the activity of approx. $30 \%$ of all genes. Some miRNAs are expressed in all tissues, while others are tissue-specific. The miRNA present in the endothelium are called angiomiRs and are presumably involved in tumor development and angiogenesis through regulation of proand/or antiangiogenic factors [7].

\section{PROANGIGENIC PROPERTIES OF MicrORNA}

Angiogenesis is a key process necessary for tumor growth. This process supplies the tumor with oxygen and nutrients, especially during later disease stages [2]. Mounting evidence 
suggests that proangiogenic miRNA are involved in angiogenesis, which increases new blood vessel formation within the neoplastic tissue. Currently, proangiogenic miRNAs include: miR-9, miR-27a, miR-30d, miRo-130b, miR-139, miR-146a, miR150, miR-155, miR-200c, miR-296 and miR-558.

Screening tests aimed at identifying miRNAs that support angiogenesis show that miR-9 is the most important factor for neovascularisation. Zhuang et al. found that elevated miR-9 in primary human umbilical vein endothelial cells (HUVEC) causes visible changes in cell morphology. Specifically, the cells become prolonged with numerous lamellipodia at their edges, changes that suggest increased mobility. Manipulating miR-9 activity in HUVECs, via inhibition or elevating its concentration, enables the study of its molecular mode of action. Elevated miR-9 increases STAT1, STAT3 and JAK2 phosphorylation, while SOCS5, a negative regulator of the JAK-STAT pathway, is significantly decreased. Thus, the SOCS5 gene is the miR-9 molecular target. This data was confirmed by the use of 4 independent algorithms (miRandy, miRtarget2, TargetScan and PicTar), which revealed that miR-9 possesses 2 putative binding sites for the SOCS53'-untranslation region (UTR) that leads to its silencing. The study indicates that increased miR-9 causes excessive JAK-STAT pathway activation that contributes to neovascularisation [18].

In thyroid cancer, miR-27a plays an important role in tumor angiogenesis. Its elevated concentration correlates with the more invasive nature of cancer cells. Wang et al. demonstrated that increased miR-27a enhances thyroid cancer cell migration. In vivo analysis revealed that mice with an increased miRNA27a concentration have elevated inducible nitric oxide synthase (iNOS) levels, which is an early marker of angiogenesis, compared to control animals. Further, immunohistochemical staining to detect neovascular density showed that mice with high miR-27a concentrations had the highest level of CD105, which was within $70 \%$ (in the control mice, $\mathrm{CD} 105$ levels were around $50 \%)$. When miR-27a was silenced with the help of a specific CD105 inhibitor, the level was maintained within 10\%. These data suggest that miR-27a participates in angiogenesis; however, further research is necessary to better understand its molecular mechanism of action [19].

Numerous studies indicate that miR-30d may be involved in prostate cancer pathogenesis. It is significantly elevated in patients diagnosed with prostate cancer, a finding that makes it a potentially excellent marker for screening. However, little is known about how miR-30d affects the growth and malignancy of this cancer. Lin et al. focused their studies on the effect of miR-30d on angiogenesis. Mice implanted with cancer cells that stably expressed miR-30d showed more advanced angiogenesis compared to control animals where miR-30d was silenced (using sh-30d). Gene expression analysis revealed that miR-30d targets MYPT1, which encodes the main component of the RhoA signaling pathway that is involved in the formation of tumor metastases. Further experiments determined that increasing the miR3od concentration activates c-JUN and increases the VEGFA concentration, results that indicate miR-30d stimulates angiogenesis in prostate cancer cells via the MYPT1/c-JUN/ VEGFA pathway [20].

MicroRNA-130b is widely known for its pro-tumor properties. It is elevated in more than $60 \%$ of sporadic cases of colorectal cancer, and its detection in serum and/or cancerous tissue is associated with a worse prognosis. There is myriad evidence that miR-13ob increases cancer cell proliferation and the epithelial mesenchymal transition (EMT). Elevated miR$130 \mathrm{~b}$ is much more common in patients with advanced cancer, especially when distant metastases and tumor-derived blood vessel network are apparent. Experiments that examined the genes involved in proliferation, EMT and angiogenesis showed immunopositivity for Ki-67 and VEGF, results that reveal the strong association of miR-130b with the recruitment potential of blood vessels and proliferation. Colangelo et al. conducted a series of in vitro and in vivo studies aimed at understanding the effect of increased miR-13ob on colorectal cancer biology. Transplantation of tumor cells with increased miR-130b were better vascularised compared to tumors from anti-miR13ob-treated mice. Further immunohistochemical analyses confirmed the presence of immunopositive tissue vascular indicators, namely collagen, CD31 and VEGF type IV, in mice with high miR-130b. Thus, the molecular target of miR-130b is peroxisome proliferator-activated $\gamma$ (PPAR $\gamma$ ) receptor. Silencing PPAR $\gamma$ expression increases VEGF expression and thus favours neoangiogenesis [21].

Li et al. analysed miRNA levels in pancreatic tumors and normal endothelial cells. Fourteen miRNAs were elevated in the tumor tissue: hsa-miR-139-5p, hsa-miR-182, hsa-miR-183, hsa-miR-192, hsa-miR-194, hsa-miR-200a, hsa-miR-20ob *, hsamiR-20ob, hsa-miR-200c, hsa-miR-203, hsa-miR-25 *, hsa-miR27a*, hsa-miR-375, hsa-miR-92a 1 *, miR-182, miR-183, miR-192, miR-194, the miR-200 family, miR-203, miR-27a *, miR-375 and miR-92a-1; they are part of the angiomiR group. Further analyses focused on miR-139 and miR-200c, because their concentration in cancer cells was more than 20 times higher than in healthy cells. The team demonstrated the proangiogenic properties of miR-139 and miR-200c through an in vitro capillary formation experiment. Cells that expressed high levels of these miRNAs produce longer tubes, and the number of loops they create is much higher than in the case of anti-miR-139 and anti-miR-200c-stimulated cells [22]. The miR-139 mechanism of action is based on CXCR4 receptor activity inhibition, while the molecular target for miR-200c is the ZEB gene. Both the ZEB gene and CXCR4 are involved in EMT regulation during neoplastic transformation, which affects repression of E-cadherin, VEGFA, FLT1, IKK $\beta$, KLF9 and TIPM2 [23, 24].

In hepatocellular carcinoma, miR-146a plays a significant role in angiogenesis. Zhu et al. demonstrated that co-culturing normal HUVECs and hepatocellular carcinoma cells stimulates epithelial cells to form new blood vessels; miR-146a is responsible for this process, and thus they focused on its proangiogenic properties in HUVECs. Transfection of normal epithelial cells with a miR-146a-containing myeloma increases proliferation, migration and the ability to form capillaries. Further studies 
conducted in a mouse model revealed an increased number of blood vessels in the immediate tumor environment in mice with elevated miR-146a compared to control animals. Molecular analysis using microarrays showed significant differences in the expression of 2497 genes between control and high-miR146a-expressing HUVECs. Of these changes, PDGFRA, which codes for the proangiogenic PDGF subunit A (PDGFA) receptor, aroused the greatest interest. MicroRNA-146a promotes PDGFRA expression by inhibiting BRCA1 gene transcription, a phenomenon that contributes to neovascularisation [25].

Cancer tissues produce a special microenvironment that positively affects tumor growth. Increasing evidence indicates that neovascularisation may be aided by macrophages located near the tumor, which are capable of synthesising proangiogenic growth factors such as VEGF, TNF- $\alpha$ and TGF- $\beta$ [26]. Liu et al. showed that macrophages present in cancer tissue remain under the strict control of miR-150, whose elevated concentration stimulates VEGF synthesis. Culturing macrophages isolated from mouse sarcoma in the presence of miR-150-expressing THP-1 cells increases VEGF secretion by the macrophages, a phenomenon that influences tumor growth. Further in vivo analyses clearly indicated that miR-150 significantly accelerates tumor growth and angiogenesis. The research team also proved that miR-150 inhibition suppresses VEGF secretion, findings confirmed by immunohistochemical staining. Mice injected with the miR-150 inhibitor show low CD31 expression, which indicates reduced neovascularisation [27].

\section{ANTIANGIOGENIC PROPERTIES OF MIRNA}

In addition to the stimulating effect of miRNA on angiogenesis, they may inhibit blood vessel development and thus tumor progression. The antiangiogenic properties of miRNAs may involve slowing down tumor growth dynamics, invasion and/or metastasis [28]. Weakening or inhibiting blood vessel formation in the development of malignant tumors may constitute an attractive therapeutic goal and a modern strategy for oncological treatment. MicroRNAs with antiangiogenic activity include but are not limited to: miR-145, miR-519c, miR-22, miR20a, miR-92, miR-7b, miR-221, miR-222, miR-328 and miR-101 [29]

Poliseno et al. utilised HUVECs, an in vitro model for angiogenesis research. These cells can create, in response to appropriate stimuli, capillary structures called 'tubes' [30,31]. The researchers examined whether miRNAs are involved in post-transcriptional modulation of angiogenesis-related genes. The results suggest that transfection of endothelial cells with miR-221 and miR-222 significantly inhibits angiogenesis in vitro by blocking the formation of tubular structures. Additionally, these miRNAs significantly reduce migration and limit wound healing. MicroRNA-221 and miR-222 reduce the level of c-Kit protein, which is involved in the regulation of many physiological processes, including cell differentiation, proliferation and maturation. These changes were not apparent at the mRNA level, and thus miR-221 and miR-222 affect c-Kit expression by blocking its translation [31]. Another study aimed to silence the Dicer enzyme. MicroRNA-221 and miR-222 overexpression indirectly reduces endothelial nitric oxide synthase (eNOS) expression. This enzyme regulates vascular function, and a reduction in its activity via miR-221 and miR-222 may cause endothelial cell dysfunction, including inhibition of tube structure formation, migration and wound healing. Blocking eNOS and the c-Kit receptor with miRNA may prove to be an important tool to inhibit blood vessel formation [32].

MicroRNA-22 also significantly modulates angiogenesis. It is expressed in most tissues, with the highest levels in the heart, smooth muscle, bladder and adipose tissue. Additionally, miR-22 is expressed in many cancer cell lines, including colon cancer. A study performed on the HCT116 cell line confirmed a correlation between miR-22 and hypoxia-inducible factor 1-alpha (HIF-1 $\alpha$ ). Excess miR-22 activity inhibits HIF-1 $\alpha$ expression while suppressing the production of VEGF in the hypoxic state. In turn, silencing endogenous miR-22 increases the expression of HIF- $1 \alpha$ and VEGF induced by hypoxia and consequently leads to the formation of new blood vessels [33].

The growing interest in the role of miRNAs in angiogenesis allowed the isolation of 2 more miRNAs that can play an important role in blood vessel formation. MicroRNA-15b and miR-16 are significantly reduced under hypoxic conditions in the human nasopharyngeal tumor (CNE) cell line. Additionally, miR-15b and miR-16 control VEGF expression, a key factor involved particularly with tumor angiogenesis. Vascular endothelial growth factor levels increase due to hypoxia-induced miR-15b, and miR16 declines. Thus, increasing these miRNA concentrations may reduce VEGF and inhibit angiogenesis [34].

Umezu et al. conducted a study on bone marrow stromal cells (BMSCs), a human multiple myeloma cell line. They observed that despite similarities in the size and quantity of exosomes, the expression profile of exosomal miRNA varies significantly depending on the BMSC donor age. Exosomal miR-340 from young BMSC donors inhibits angiogenesis via the HGF/c-MET signaling pathway. The antiangiogenic nature of exosomes from older BMSC donors is restored by direct transfection of exosomal RNA from young BMSCs. This data provides a new outlook on anticancer therapy based on exosome modifications [35].

MicroRNA-145 also exerts antiangiogenic effects through direct suppression of receptors associated with tyrosine kinase activity. During actively progressing cancer, its expression is reduced. MicroRNA-145 is significantly reduced in both tissues and cell lines of colon and ovarian cancer. MicroRNA-145 inhibits p70S6K1 expression by binding to the 3'-UTR region of the gene. Consequently, the signal transduction pathway that activates VEGF and HIF-1 is inhibited. This inhibition suppresses tumor growth and impairs antiangiogenic functions [36].

MicroRNA-519c reduces angiogenesis by direct binding to the HIF-1 $\alpha$ 3'-UTR end. MicroRNA-519c overexpression significantly reduces HIF- $1 \alpha$ and abrogates new blood vessel formation, phenomena that are closely related to the inhibition of tumor growth and metastases. Additionally, miR-519c can even regulate HIF-1 $\alpha$ under hypoxic conditions, since low oxygen does not affect miR-519c expression. Further, hepatocyte growth factor (HGF), a known HIF-1 $\alpha$ inducer, reduces miR-519c 
by affecting the Akt-dependent pathway. The above data indicate that miR-519c is a key regulator of tumor angiogenesis, and its biogenesis in tumor cells is regulated by HGF [37].

\section{REFERENCES}

1. Kurzyk A. Angiogeneza - możliwości, problemy, perspektywy. Post Bioch 2015;61(1):25-34

2. Banyś A, Bułaś L, Długosz E, Szulc-Musiał B, Jankowski A. Angiogeneza w chorobie nowotworowej. Patofizjologia 2009;65(4):247-50.

3. Tomczyk M, Nowak W, Jaźwa A. Śródbłonek w fizjologii i patogenezie chorób. Post Bioch 2013;59(4):357-64.

4. Szala S, Jarosz M. Nowotworowe naczynia krwionośne. Post Hig 2011;65:437-46.

5. Sacewicz I, Wiktorska M, Wysocki T, Niewarowska J. Mechanizmy angiogenezy nowotworowej. Post Hig 2009;63:159-68.

6. Szala S. Angiogeneza i immunosupresja: jin i jang progresji nowotworów? Post Hig 2009;63:598-612.

7. Suarez Y, Sessa WC. MicroRNAs as novel regulators of angiogenesis. Circ Res 2009;104(4):442-54.

8. Filip A. MikroRNA: nowe mechanizmy regulacji ekspresji genów. Post Bioch 2007;53(4):413-9.

9. Du T, Zamore PD. microPrimer: the biogenesis and function of microRNA. Development 2005;132(21):4645-52.

10. Pillai RS. MicroRNA function: Multiple mechanisms for a tiny RNA? RNA 2005;11(12):1753-61.

11. Grenda A, Budzyński M, Filip AA. Biogeneza cząsteczek mikroRNA oraz ich znaczenie w powstawaniu i przebiegu wybranych zaburzeń hematologicznych. Post Hig 2013;67:174-85.

12. Król J, Loedige I, Filipowicz W. The widespread regulation of microRNA biogenesis, function and decay. Nat Rev Genet 2010;11(9):597-610.

13. Bujak J, Kopytko P, Lubecka M. miRNA markerami chorób nowotworowych. Nauka, Badania i Doniesienia Naukowe 2017;1:269-77.

14. Kim VN. MicroRNA biogenesis: coordinated cropping and dicing. Nat Rev Mol Cell Biol 2005;6(5):376-85.

15. Hukowska-Szematowicz B, Deptuła W. Biologiczna rola mikroRNA (miRNA) - nowe dane. Post Biol Komórki 2010;37(3):585-97.

16. John B, Enright AJ, Aravin A, Tuschl T, Sander C, Marks DS. Human microRNA targets. PLoS Biol 2004;2(11):e363.

17. Zeng Y, Wagner EJ, Cullen BR. Both natural and designed microRNAs can inhibit the expression of cognate mRNAs when expressed in human cells. Mol Cell 2002;9(6):1327-33.

18. Zhuang G, Wu X, Jiang Z, Kasman I, Yao J, Guan Y, et al. Tumour-secreted miR-9 promotes endothelial cell migration and angiogenesis by activating the JAK-STAT pathway. EMBO J 2012;31(17):3513-23.

19. Wang YL, Gong WG, Yuan QL. Effects of miR-27a upregulation on thyroid cancer cells migration, invasion, and angiogenesis. Genet Mol Res 2016;15(4):1-10. doi:10.4238/gmr15049070.

20. Lin ZY, Chen G, Zhang YQ, He HC, Liang YX, Ye JH, et al. MicroRNA-30d promotes angiogenesis and tumor grow th via MYPT1/c-JUN/VEGFA pathway and predicts aggressive outcome in prostate cancer. Mol Cancer 2017;16(1):48. doi:10.1186/s12943-017-0615-x.
21. Colangelo T, Fucci A, Votino C, Sabatiano L, Pancione M, Laudanna C, et al. MicroRNA-130b promotes tumor development and is associated with poor prognosis in colorectal cancer. Neoplasia 2013;15(9):1086-99.

22. Li L, Li B, Chen D, Liu L, Huang C, Lu Z, et al. miR-139 and miR-200c regulate pancreatic cancer endothelial cell migration and angiogenesis. Oncol Rep 2015;34(1):51-8.

23. Luo HN, Wang ZH, Sheng Y, Zhang Q, Yan J, Hou J, et al. miR-139 targets CXCR4 and inhibits the proliferation and metastasis of laryngeal squamous carcinoma cells. Med Oncol 2014;31(1):789. doi:10.1007/s12032013-0789-z.

24. Chuang TD, Panda H, Luo X, Chegini N. miR-200c is aberrantly expressed in leiomyomas in an ethnic-dependent manner and targets ZEBs, VEGFA, TIMP2, and FBLN5. Endocr Relat Cancer 2012;19(4):541-56.

25. Zhu K, Pan Q, Zhang X, Kong LQ, Fan J, Dai Z, et al. MiR-146a enhances angiogenic activity of endothelial cells in hepatocellular carcinoma by promoting PDGFRA expression. Carcinogenesis 2013;34(9):2071-9.

26. Bolat F, Kayaselcuk F, Nursal TZ, Yagmurdur MC, Bal N, Demirhan B. Microvessel density, VEGF expression, and tumor-associated macrophages in breast tumors: correlations with prognostic parameters. J Exp Clin Cancer Res 2006;25(3):365-72.

27. Liu Y, Zhao L, Li D, Yin Y, Zhang CY, Li J, et al. Microvesicle-delivery miR-150 promotes tumorigenesis by up-regulating VEGF, and the neutralization of miR-150 attenuate tumor development. Protein Cell 2013;4(12):932-41.

28. Markowska A, Jaszczyńska-Nowinka K, Kaysiewicz J, Makówka A, Markowska J. Angiogeneza w złośliwych nowotworach ginekologicznych. Curr Gynecol Oncol 2015,13(4):256-62.

29. Baczyńska D, Michałowska D, Witkiewicz W. Rola mikroRNA w chorobach niedokrwiennych - wpływ na regulację procesów zapalnych, apoptozy i angiogenezy. Prz Lek 2014;70(3):135-42.

30. Matsui J, Wakabayashi T, Asada M, Yoshimatsu K, Okada M. Stem cell factor/c-kit signaling promotes the survival, migration, and capillary tube formation of human umbilical vein endothelial cells. J Biol Chem 2004;279(18):18600-7.

31. Poliseno L, Tuccoli A, Mariani L, Evangelista M, Citti L, Woods K, et al. MicroRNAs modulate the angiogenic properties of HUVECs. Blood 2006;108(9):3068-71.

32. Suárez Y, Fernández-Hernando C, Pober JS, Sessa WC. Dicer dependent microRNAs regulate gene expression and functions in human endothelial cells. Circ Res 2007;100(8):1164-73.

33. Yamakuchi M, Yagi S, Ito T, Lowenstein CJ. MicroRNA-22 regulates hypoxia signaling in colon cancer cells. PLoS One 2011;6(5):e20291.

34. Hua Z, Lv Q, Ye W, Wong CK, Cai G, Gu D, et al. MiRNA-directed regulation of VEGF and other angiogenic factors under hypoxia. PLoS One 2006;1: e116.

35. Umezu T, Imanishi S, Azuma K, Kobayashi C, Yoshizawa S, Ohyashiki $\mathrm{K}$, et al. Replenishing exosomes from older bone marrow stromal cells with miR-340 inhibits myeloma-related angiogenesis. Blood Adv 2017;1(13):812-23.

36. Xu Q, Liu LZ, Qian X, Chen Q, Jiang Y, Li D, et al. MiR-145 directly targets p70S6K1 in cancer cells to inhibit tumor growth and angiogenesis. Nucleic Acids Res 2012;40(2):761-74.

37. Cha ST, Chen PS, Johansson G, Chu CY, Wang MY, Jeng YM, et al. MicroRNA519c suppresses hypoxia-inducible factor-1alpha expression and tumor angiogenesis. Cancer Res 2010;70(7):2675-85. 